\title{
Dialister micraerophilus
}

National Cancer Institute

\section{Source}

National Cancer Institute. Dialister micraerophilus. NCI Thesaurus. Code C122280.

A species of Gram-negative, non-motile, non-sporulating, rod-shaped bacteria in the family Veillonellaceae. D. micraerophilus is generally anaerobic but will also grow under microaerophilic conditions. It can be differentiated from other Dialister species by phenylalanine arylamidase activity and tyrosine arylamidase activity. 